\title{
Hubungan Komformitas Teman Sebaya dengan Sikap Terhadap Perilaku Seksual pada Remaja Di SMA Krakatau Medan
}

\section{Correlation between peer-to-peer conformity and attitudes towards sexual behavior among adolescents at SMA Krakatau Medan}

\author{
Dita Amalia Sardi Malau(1) \& Istiana(2)* \\ Fakultas Psikologi, Universitas Medan Area, Indonesia
}

Disubmit: 18 Oktober 2020; Diproses: 18 Oktober 2020; Diaccept: 16 November 2020; Dipublish: 01 Desember 2020 *Corresponding author: E-mail: istiana@staff.uma.ac.id

\begin{abstract}
Abstrak
Penelitian ini bertujuan untuk melihat hubungan antara komformitas teman sebaya dengan sikap terhadap perilaku seksual. Penelitian ini menggunakan pendekatan kuantitatif dengan desain korelasional.hipotesis yang diajukan : ada hubungan yang positif antara komformitas teman sebaya dengan sikap terhadap perilaku seksual dan adanya perbedaan sikap terhadap perilaku sexual antara laki-laki dan perempuan.dalam hal ini remaja yang memiliki kompormitas teman sebaya yang tinggi akan lebih bersikap positif terhadap perilaku seksual, sebaliknya remaja yang memiliki komformitas teman sebaya yang rendah akan lebih negatif sikapnya terhadap perilaku seksual. Sampel penelitian ini adalah siswa-siswi SMA Krakatau Medan berjumlah 118 orang teknik pengambilan sample adalah total sampling. Metode pengumpulan data menggunakan skala likert untuk skala kompormitas teman sebaya dan sikap terhadap perilaku sexual. Analisis data menggunakan Product Moment dan Anava satu jalur berdasarkan hasil perhitungan analisis Product Moment diperoleh koefisien hubungan sebesar 0,$45 ; p=0,000(p<0,050)$ artinya ada hubungan yang signifikan antara komformitas teman sebaya dengan sikap terhadap perilaku sexual. Komformitas teman sebaya menyumbang atau mempengaruhi sikap terhadap perilaku seksual sebesar 16,4\%. Sedangkan nilai koefisien anava satu jalur sebesar 18,657; $\mathrm{p}=0,000(\mathrm{p}<0,050)$ artinya ada perbedaan sikap terhadap perilaku sexual antara laki-laki dan perempuan.
\end{abstract}

Kata Kunci: Komformitas Teman Sebaya; Sikap Terhadap Perilaku Seksual; Remaja

\begin{abstract}
This study aims to see the correlation between peer conformity with attitudes toward sexual behavior. This study uses a quantitative approach with a correlational design. The hypothesis proposed: there is a positive correlation between peer conformity with attitudes towards sexual behavior and there is a difference in attitudes towards sexual behavior between men and women. In this case, adolescents who have peer conformity High will be more positive about sexual behavior, conversely adolescents who have low peer conformity will have more negative attitudes toward sexual behavior. The sample of this study were 118 students of SMA Krakatau Medan. The sampling technique was total sampling. The method of data collection uses a Likert scale to scale the peer conformity and attitudes towards sexual behavior. Data analysis using Product Moment and Anava one path based on the calculation results of Product Moment analysis obtained a correlation coefficient of $0.45 ; p=0.000(p<0.050)$ means that there is a significant correlation between peer conformity and attitudes towards sexual behavior. Peer conformity contributed to or influenced attitudes towards sexual behavior by $16.4 \%$. While the one-way ANOVA coefficient value is 18.657; $p=0.000(p<0.050)$ means that there are differences in attitudes towards sexual behavior between men and women.
\end{abstract}

Keywords: Peer Compensation; Attitudes Toward Sexual Behavior; Adolescents

Rekomendasi mensitasi:

Malau, D.A.S., \& Istiana, 2020. Hubungan Komformitas Teman Sebaya dengan Sikap Terhadap Perilaku Seksual pada Remaja Di SMA Krakatau Medan. Jurnal Penelitian Pendidikan, Psikologi dan Kesehatan (J-P3K), 1(3): 211-217. 


\section{PENDAHULUAN}

Masa remaja merupakan suatu dimana individu mengalami fase peralihan dari masa kanak-kanak menuju fase dewasa. Pada masa ini, salah satu tugas perkembangan adalah mencapai hubungan baru yang lebih dan lebih matang dengan teman sebaya baik dengan lawan jenis ataupun sesama jenis. Ketika mereka secara seksual sedah matang, lakilaki maupun perempuan mulai mengembangkan sikap yang baru pada lawan jenisnya dan mengembangkan minat terhadap lawan jenisnya khususnya minat terhadap seks (Hurlock, 1990).

Pada tahap perkemmbangan inilah, dimana individu mempunyai keingintahuan yang besar untuk mencoba dan mengetahui dunia baru terutama yang berhubungan dengan masalah seksual. Permasalahan seksual selalu menjadi topic yang menarik untuk dibicarakan sampai saat ini. Hal ini dimungkinkan karena permasalahan seksual telah menjadi suatu hal yang sangat melekat pada diri manusia khususnya remaja. Permasalahan seksual di kalangan remaja saat ini memang sangatlah memprihatinkan. Dari tahun ke tahun kasus mengenai seksual di Indonesia semakin banyak jumlahnya, dan tidak dapat dipungkiri bahwa sebagian pelakunya adalah remaja.

Menurut Sarwono (2008), perilaku seksual itu adalah bentuk tingkah laku yang di sorong oleh hasrat seksual dengan lawan jenis atau dengan diri sendiri, objek seksualnya bisa berupa orang lain, orang dalam khayalan atau diri sendiri.

Sikap merupakan salah satu aspek psikologis individu yang sangat penting karena sikap merupakan kecenderungan untuk berperilaku sehingga akan banyak mewarnai seseorang. Sikap adalah cara seseorang melihat sesuatu secara mental (dari dalam diri) yang mengarah dalam perilaku yang ditunjukkan pada orang lain, objek maupun kelompok tertentu. Sikap adalah cara seseorang mengkomunikasikan perasannya pada orang lain (melalui perilaku). Jika perasaan seseorag terhadap sesuatu adalah positif maka akan terpancar pula perilaku positif dari individu bersangkutan menyikapi sesuatu yang dihadapinya itu, dan sebaliknya.

Sikap terhadap perilaku seksual bisa berwujud positif ataupun negatif. Jika sikap tersebut positif maka akan berperilaku positif dengan kecendrungan tindakan adalah mendukung perilaku seksual sedangkan jika sikap tersebut negatif maka akan berperilaku negatif maka akan negatif pula dengan kecenderungan tindakan adalah menghindari perilaku seksual. Salah satu faktor yang mempengaruhi sikap terhadap perilaku seksual adalah pengaruh orang lain yang dianggap penting. Individu cenderung untuk memiliki sikap yang komformis atau searah dengan sikap orang yang dianggapnya penting.

Menurut Monks (2001) komformitas adalah penyesuaian remaja terhadap norma dengan berperilaku sama dengan kelompok teman sebaya. Adanya komformitas dapat dilihat dari perubahan perilaku atau keyakinan remaja karena tekanan dari kelompok. Komformitas muncul ketika individu meniru sikap atau tingkah laku orang lain, dalam hal ini teman sebaya, karena adanya tekanan yang nyata maupun yang dibayangkan oleh mereka (Santrock, 2003). Salah satu 
alasan utama remaja melalukan komformitas adalah demi memperoleh persetujuan atau menghindari celaan kelompok. Hal ini yang memicu remaja untuk melakukan apa yang dilakukan anggota kelompok dalam berbagai hal (Hurlock, 1990).

Komformitas teman sebaya pada remaja dapat memberikan dampak positif dan negatif bagi remaja itu sendiri, misalnya dampak positif komformitas jika kelompok dimana individu tersebut berada sering melakukan belajar bersama, maka secara tidak langsung individu tersebut terlibat di dalamnya. Komformitas pun dapat memberikan dampak negatif seperti minum-minuman beralkohol, merokok, pola hidup konsumtif, tawuran, menggunakan obat terlarang, ataupun berhubungan seksual.

Menurut Cougan (Asriani, 2004) juga mengatakan bahwa aktivitas seksual lebih banyak terjadi pada remaja pria, karena dorongan seksual lebih bersifat mutlak dibandingkan remaja wanita yang lebih dirasakan tidak jelas dan tertutup. Hal ini disebabkan adanya perbedaan fisiologis antara remaja pria dan remaja wanita dalam merespon dorongan seksualnya.

Masa remaja dimulai kira-kira antara usia 10-13 tahun dan berakhir kira-kira antara usia 18-22 tahun (Santrock, 2003). Masa remaja, menurut Mappiare (Ali \& Ansari, 2010) berlangsung antara umur 12 sampai dengan 21 tahun bagi wanita dan 13 tahun sampai 22 tahun bagi pria. Rentang usia ini dapat dibagi menjadi dua bagian yaitu usia 12-13 tahun sampai dengan 17-18 tahun adalah remaja awal dan usia 17-18 tahun sampai 21-22 tahun adalah remaja akhir.
Aspek-aspek perkembangan pada remaja menurut Ali \& Ansari (2010) adalah:

a. Perkembangan Fisik

b. Perkembanga Kepribadian

c. Perkembangan Emosi

d. Perkembangan Interaksi sosial remaja

e. Perkembangan Moral remaja

Bird (Natalia, 2011), mengartikan sikap sebagai suatu yang berhubungan dengan penyesuaian diri seseorang kepada aspek-aspek lingkungan sekitar yang dipilih atau tindakan sendiri. Bahkan lebih luas lagi, sikap dapat diartikan sebagai prediposisi (kecenderungan jiwa) atau orientasi kepada suatu masalah, intitusi dan orang lain.

Thurstone mendefinisikan sikap sebagai derajat afek positif dan afek negatif terhadap suatu objek psikologis. Lapierre mendefinisikan sikap sebagai suatu pola perilaku, tendensi, atau kesiapan antisipatif, predisposisi untuk menyesuaikan diri dalam situasi sosial, atau secara sederhana, sikap adalah trespon terhadap stimulus sosial yang telah terkondisikan. Definisi Petty \& Cacioppo secara lengkap mengatakan siakp adalah evaluasi umum yang dibuat manusia terhadap dirinya sendiri, orang lain, obyek atau isu-isu (Azwar, 2007).

Mu'tadin (Oktamilia, 2010), menyatakan bahwa perilaku seksual adalah perilaku yang melibatkan sentuhan secara fisik anggota badan antara pria dan wanita yang telah mencapai pada tahap hubungan intim, yang biasa dilakukan pasangan suami istri.

Perilaku seksual itu adalah bentuk tingkah laku yang didorong oleh hasrat seksual dengan lawan jenis atau dengan 
diri sendiri, objek seksualnya bisa beupa orang lain, orang dalam khayalan atau diri sendiri (Sarwono, 2008). Perilau seksual adalah tingkah laku yang berhubungan dengan manifestasi seksual dan naluri seksual yang merupakan rangsangan fisik yang bertujuan untuk mencari kepuasan. Perilaku seksual adalah segala tingkah laku yang disorong oleh hasrat seksual dengan lawan jenis ataupun sesama jenis. Bentuk-bentuk tingkah laku ini bisa bermacam-macam, mulai dari perasaan tertarik sampai tingkah laku berkencan, bercumbu, dan bersenggama (Sarwono, 2008).

Menurut Baron \& Byrnee (2005) komformitas adalah penyesuaian perilaku untuk menganut pada norma kelompok acuan, menerima ide atau aturan-aturan yang menunjukkan bagaimana seseorang individu akan berperilaku.

Laki-laki dan perempuan memiliki perbedaan fisik, psikologis dan peran yang diberikan oleh masyarakat sesuai dengan kebudayaan. Perbedaan pandangan dalam menerima sikap informasi diantara pria dan wanita, menyebabkan presentase yang berbeda pula dalam bersikap dan berperilaku terhadap seks tersebut. Menurut Sarwono (2008) di Indonesia sikap pria pada umumnya lebih pesimis daripada wanita.

Menurut Toruserizawa (Asriani, 2004), wanita agak kurang memperoleh informasi mengenai seks dibandingkan pria. Bagi pria dapat saja saling tukar mengenai seks dengan teman serta membaca buku porno. Bagi wanita tidak berani secara terbuka memperbincangkan masalah seks dengan temannya, serta kurang berani atau sedikit enggan membaca buku mengenai seks.
Pada masa ini, remaja dan perilaku seksual adalah dua hal yang sangat berhubungan erat sehingga tidak dapat dipisahkan. Hal itu disebabkan pada fase remaja mereka pada umumnya memiliki dorongan dan keingintahuan yang sangat kuat membuat mereka mencari sumber pengetahuan dan informasi mengenai masalah seksualitas.

Bruess dan Greenberg (Prihastuti, 2010), menyatakan bahwa sebagian remaja mendapatkan informasi seputar masalah perilaku seksual dari media massa dan teman sebaya. Leary \& Dooginis (Prihastuti, 2010), mengatakan bahwa teman sebaya seringkali memberikan informasi yang mennyesatkan remaja. Ini dikarenakan remaja menganggap teman sebaya sesuatu yang paling pening pada saat ini dan remaja lebih nyaman bercerita dengan teman sebaya daripada orangtua. Kecenderungan remaja untuk melihat dengan perilaku seksual. Sikap positif terhadap perilaku seksual dari teman sebaya akan ditiru oleh remaja sebagai bentuk dari loyalitas mereka terhadap kelompok teman sebaya.

\section{METODE PENELITIAN}

Penelitian ini menggunakan pendekatan kuantitatif dalam menguji hipotesis yang telah disusun. Dengan skala yang digunakan dalam mengukur Komformitas Teman sebaya dan Sikap terhadap Perilaku seksual adalah menggunakan skala psikologi yang diformat dalam bentuk likert.

Populasi dalam penelitian ini adalah para siswa-siswi yang sedang bersekolah di SMA Krakatau Medan dengan jumlah 169 siswa-siswi. Sedangkan sample dalam 
penelitian ini berjumlah 118 orang dari siswa-siswi kelas XI dan XII, yang dimana dalam pengambilan sampel teknik yang digunakan adalah purposive sampling. Purposive sampling adalah dimana dalam pengambilan sampel sesuai dengan kriteria yang dikehendaki peneliti.

Dalam penelitian ini digunakan dua macam skala alat ukur, yaitu skala Komformitas teman sebaya, yang diambil dari aspek-aspek komformitas yang dikemukakan oleh Sears (Khafini, 2010) yaitu: kekompakan, kesepakatan dan ketaatan. Dan skala sikap terhadap perilaku seksual yang disusun berdasarkan komponen/aspek-aspek sikap yang dikemukakan oleh Azwar (2007) yang meliputi: Aspek Kognitif, Afektif, dan Konatif terhadap perilaku seksual yakni berfantasi, berpegangan tangan, cium kering, cium basah, meraba, masturbasi, oral, petting dan Intercourse.

Analisis yang digunakan dalam penelitian ini adalah teknik korelasi product moment dari Pearson.

\section{HASIL DAN PEMBAHASAN}

Berdasarkan hasil perhitungan Korelasi Product Moment dengan maksud untuk mengungkap hubungan antara komformitas teman sebaya dengan sikap terhadap perilaku seksual di SMA Krakatau Medan dengan (Rxy $=0,405 ; \mathrm{p}=$ $0.000<0,050$ ). Dari hasil korelasi ini, maka dapat dinyatakan hipotesis yang diajukan dalam penelitian ini diterima, yakni artinya semakin tinggi komformitas teman sebaya, maka semakin positif sikap terhadap perilaku seksual. Sebaliknya semakin rendah komformitas teman sebaya, maka semakin negatif sikap terhadap perilaku seksual Adapun koefisien determinan $\left(r^{2}\right)$ dari hubungan diatas sebesar $=0,164$. Hal ini menunjukkan bahwa sikap terhadap perilaku seksual dibentuk oleh komformitas teman sebaya sebesar $16,4 \%$. Selebihnya $83,6 \%$ sikap terhadap perilaku seksual dibentuk atau dipengaruhi oleh faktor-faktor lain yang dalam penelitian ini tidak diteliti.

Table 1. Rangkuman hasil analisis Product Moment

\begin{tabular}{lllll}
\hline statistik & $\begin{array}{l}\text { Koefisien } \\
\text { (rxy) }\end{array}$ & $\begin{array}{l}\text { Koef.Det } \\
(\mathrm{r} 2)\end{array}$ & $\mathrm{p}$ & $\mathrm{BE} \%$ \\
\hline $\mathrm{X} ; \mathrm{Y}$ & 0,405 & 0,164 & 0.000 & $16,4 \%$ \\
\hline
\end{tabular}

Selanjutnya berdasarkan hasil Anova 1 jalur, dengan ini diketahui bahwa terdapat perbedaan sikap terhadap perilaku seksual antara laki-laki dan perempuan $(\mathrm{F}=18,657 ; \mathrm{p}<0,050)$ diamana mean laki-laki $(\mathrm{A} 1)=120,55$, sedangkan mean perempuan (A2) = 104,91. Untuk mencantumkan sikap terhadap perilaku seksual antara laki- laki dan perempuan adalah nilai mean empirik dan mean hipotetik. Apabila mean hipotetik < mean empirik, maka dinyatakan bahwa sikap terhadap perilaku seksual positif dan apabila mean hipotetik > mean empirik, maka sikap terhadap perilaku seksual negatif.

Tabel 2. Rangkuman Analisis Varians 1 Jalur

\begin{tabular}{|c|c|c|c|c|c|}
\hline \multirow[t]{2}{*}{ Sumber } & \multirow[t]{2}{*}{$\mathrm{N}$} & \multicolumn{2}{|c|}{ Rata -rata } & \multirow[t]{2}{*}{ SB } & \multirow[t]{2}{*}{ Ket } \\
\hline & & hipotetik & Empirik & & \\
\hline A1 & 49 & 117,5 & 120,55 & 10,35 & $\mathrm{P}$ \\
\hline $\mathrm{A} 2$ & 69 & 117,5 & 104,91 & 23,76 & $\mathrm{~N}$ \\
\hline
\end{tabular}

Berdasarkan hasil penelitian ini, diketahui bahwa komformitas teman sebaya yang dimiliki subjek penelitian ini, yakni siswa/siswi SMA Krakatau Medan dinyatakan tergolong sedang. Hal ini 
didasarkan pada nilai rata-rata mean hipotetik sebesar $130<$ mean empiriknya sebesar 135,63 dan berada diantara batas nilai -1SD sampai +1SD yang dinyatakan normal/sedang. Selanjutnya sikap terhadap perilaku seksual siswa/siswi SMA Krakatau Medan dinyatakan tergolong negatif. Hal ini berdasarkan pada nilai rata-rata mean hipotetk sebesar 117,5 > mean empiriknya sebeaar 111,40.

Sikap terhadap perilaku seksual siswa/siswi SMA Krakatau Medan tergolong negaatif dikarenakan sampel dalam penelitian ini lebih banyak perempuan daripada laki-laki, hal ini didasarkan pada nilai rata-rata mean hipotetik sebesar 117,5 > mean empiriknya sebesar 104,91. Sikap terhadap perilaku seksual pada perempuan tergolong negatif daripada laki-laki karena orangtua cenderung lebih protektif pada perempuan dan oranng tua masih memegang nilai tradisional, yaitu perempan yaitu perempuan harus menjaga dan mempertahankan kegadisannya sebelum menikah.

Tabel 3. Hasil pehitungan nilai rata-rata Hipotetik dan nilai rata-rata Empirik

\begin{tabular}{|c|c|c|c|c|}
\hline \multirow{2}{*}{ Variable } & \multicolumn{2}{|c|}{ Mean } & \multirow{2}{*}{ SB } & \multirow{2}{*}{ KET } \\
\hline & hipotetik & Empirik & & \\
\hline Komformita & & & & \\
\hline $\begin{array}{l}\text { Teman } \\
\text { sebaya }\end{array}$ & 130 & 135,16 & 11,16 & Sedang \\
\hline $\begin{array}{c}\text { Sikap } \\
\text { Terhadap } \\
\text { Perilaku } \\
\text { seksual }\end{array}$ & 117.5 & 111,40 & 20,79 & Negativ \\
\hline
\end{tabular}

\section{SIMPULAN}

Kesimpulan pada peneitian ini yang dilihat berdasarkan hasil dari perhitungan analisis korelasi Pearson Product Moment menunjukkan bahwa ada hubungan positif yang sangat signifikan antara komformtas teman sebaya dengan siakp terhadap perilaku seksual di SMA Krakatau Medan dengan Koefesien dimana $r x y=0,404 ; p=$ $0,000<0,050$. Artinya semakin tinggi komformitas teman sebaya maka semakin positif sikao terhadap perilaku seksual, sebaliknya semakin rendah komformitas maka semakin negatif perilaku seksualnya. Berdasarkan hasil penelitian yang dilakukan di SMA Krakatau Medan, maka hipotesis yang diajukan dinyatakan diterma.

Komformitas teman sebaya menyumbang atau mempengaruhi sikap terhadap perilaku seksual sebesar 16,4\% dengan demikian terdapat 83,6\% faktor lain yang tidak dibahas dipenelitian ini yang mempengaruhi sikap terhadap perilaku seksual adalah pengalaman pribadi, pengaruh kebudayaan, media, penngaruh orang tua, pemahaman dan penghayalan tentang nilai agama, dan kurangnya informasi tentang seks.

Dari analisis Anava 1 jalur diketahui juga bahwa ada perbedaan sikap terhadap perilaku seksual antara laki-laki dan perempuan yag ditujukkan dengan nilai $\mathrm{p}$ $=0,000$, berarti $\mathrm{p}<0,050$.

\section{DAFTAR PUSTAKA}

Ali, \& Ansari. (2010). Psikologi Remaja: Perkembangan Peserta Didik. Bumi Aksara: Jakarta.

Arikunto, S. (2005). Prosedur Penelitian Suatu Pendekatan Praktek. Jakarta: Rineka.

Asriani, S. (2004). Hubungan Antara Harga Diri Dengan Sikap Terhadap Seks Bebas Pada Remaja di SMP Shandy Putera Medan. Medan: Fakultas Psikologi Universitas Medan Area.

Azwar, S. (2005). Penyusunan Skala Psikologi. Yogyakarta: Pustaka Pelajar.

Azwar, S. (2007). Sikap Manusia Teori dan Pengukurannya. Yogyakarta: Pustaka Pelajar.

Baron, R. A., \& Byrnee, D. (2005). Psikologi Sosial Jilid 2. Jakarta: Erlangga.

Chintya, T. (2007). Hubungan Antara Komformitas Kelompok Dengan Perilaku 
Seks Bebas Pada Remaja. Fakultas Psikologi Universitas Gunadarma.

Desmita. (2005). Psikologi Perkembangan. Bandung: PT Remaja Rosdakarya.

Hurlock, E. B. (1990). Psikologi Perkembangan: Suatu Pendekatan Sepanjang Rentang Kehidupan. Jakarta: Erlangga.

Hutagalung, I. (2007). Pengembangan Kepribadian Tinjauan Praktis Pribadi Positif. Jakarta: PT Indeks.

Khafini, M. (2010). Hubungan Antara Komformitas Dengan Motivasi Belajar Pada Siswa-siswi SMP Istiqlal Deli Tua. Medan: Fakultas Psikologi Universitas Medan Area.

Monks, F. J. (2001). Psikologi Perkembangan: Penghantar Dalam Berbagai Bagiannya. Yogyakarta: Gajah Mada University Press.

Natalia, R. G. (2011). Perbedaan Sikap Terhadap Seks Bebas Ditinjau Dari Locus Of Control Pada Remaja di SMA Kartika 1-2 Medan. Medan: Fakultas Psikologi Universitas Medan Area.

Nisfiannooer, M. (2009). Pendekatan Statistika Untuk Ilmu Sosial. Jakarta: Salemba Humanika.

Oktamilia, E. (2010). Hubungan Antara Harga Diri Dengan Perilaku Seksual Pada Remaja Berpacaran di Kelurahan Langan Jaya 1 Kabupaten Dharmasraya Sumatera Barat. Medan: Fakultas Psikologi Universitas Medan Area.

Prihastuti, E. (2010). Hubungan Minat Terhadap Media Pornografi Dengan Perilaku Seksual Pada Remaja di SMU Swasta Taman Siswa Cabang Binjai. Medan: Fakultas Psikologi Universitas Medan Area.

Santrock, J. W. (2003). Adolescence Perkembangan Remaja Edisi Keenam. Jakarta: Erlangga.

Sarwono, S. W. (2009). Penghantar Psikologi Umum. Jakarta: Rajawali Pers.

Sarwono, S. W. (2005). Psikologi Kelompok dan Psikologi Terapan. Jakarta: Balai Pustaka.

Sarwono, S. W. (2008). Psikologi Remaja. Jakarta: PT Raja Grafindo Persada.

Widodo, U. P. (2010). Perilaku Seks Bebas Pada Seorang Alkoholik. Fakultas Psikologi Universitas Gunadarma. 